\title{
Factors Influencing Consumers Purchase Intention towards Organic and Cloned Animal Food Products
}

\author{
Priyajoy Kar $^{1 *}$, H.R. Meena ${ }^{2}$ and Neela Madhav Patnaik ${ }^{1}$ \\ ${ }^{1}$ Dairy Extension Division, ICAR-National Dairy Research Institute, \\ Karnal-13200, Haryana, India \\ ${ }^{2}$ Faculty of Dairy Extension Division, ICAR-National Dairy Research Institute, \\ Karnal-13200, Haryana, India \\ *Corresponding author
}

\begin{abstract}
A B S T R A C T
The green concept and the development of organic animal foods are still in the infant stage in India. The concept of animal cloning has gaining popularity over the last decade through the novel and revolutionary work done by ICAR-NDRI and it will have a great impact in the coming days in Indian food industry. Keeping in view the changing trend, this study explores the factors influencing purchase intention of consumers and how these factors affect the intention of consumers towards organic and cloned animal food products. With the available literature and based on theory of planned behavior, a conceptual framework is developed to examine the factors influencing the purchase intention of consumers towards organic and cloned animal food products. Data were collected from 200 respondents through pre-tested interview schedule and using convenient sampling method. The result indicated that intention to purchase organic and cloned animal food products were significantly affected by the perceived quality and risk in the food products as compared to perceived price and packaging. Significant mean differences were observed in the purchase intention according to the respondent's gender, age, income level, education level and residential area. Consumer's perception towards organic and cloned animal food products will influence their purchase intention and then lead to the actual purchase of the products. The findings proposed useful information to different private, govt, and cooperative dairy federations to develop effective marketing strategies to convince the consumers about the organic concerned segments in the food products. It will also support the entry of different food products in the Indian food market which will be available from the cloned animals which in turn would help in revolutionizing the Indian food industry.
\end{abstract}

\section{Keywords}

Organic, Cloning, Intention,

Perception,

Strategies,

Consumers

Article Info

Accepted:

04 December 2017

Available Online:

10 January 2018

\section{Introduction}

Over the last decade, consumers are worrying about the quality of the food they eat because of food crises such as mad cow disease, the foot and mouth epidemic and the Belgian dioxin scandal (Miles and Frewer, 2001). Recurring food safety incidents have raised consumers concerns about the food quality and safety (Liu, Pieniak and Verbeke, 2013). This phenomenon is reflected in a growing demand of organic produce, which is 
considered less damaging to the environment and healthier than traditionally grown foods (Mondelaers et al., 2009; Schifferstein and Oude Ophius, 1998; Williams and Hammit, 2001).

Animal cloning offers great opportunity in terms of benefit to consumers, farmers and endangered species. By means of cloning farmers-producers accelerate the reproduction of their most productive livestock in order to better produce safe and healthy food products. By the use of cloning good healthy animals are produced. It minimizes the uses of antibiotics and growth hormones. Consumers can benefit from cloning because meat and milk will be more healthy, consistent and safe. Food items from cloning will be from the next generation animals that are produced from the cloned animals. Different rare and endangered species can be protected through the technique of cloning. The Food and Drug Administration (FDA) has concluded that the composition of food products from cattle, swine and goat clones and offspring of any other animal clones is no different from that of conventionally bred animals, there are no additional risks to people eating food from cattle, swine and goat clones. The possibility of milk and meat from cloned animals entering the food supply has existed since the successful cloning of the sheep, Dolly in 1996.

Studies that have touted the positive contributions of animal cloning have included that of Stice et al., (1998), who indicated that commercial potential from cloning was simply enormous. Apart from increasing the efficiency of meat production in chicken and livestock, cloning is viewed as having large potential impacts for biomedicine and agriculture. On the other hand organic foods are not genetically modified and are produced specifically without the application of synthetic chemicals such as pesticides and fertilizers (Chen, 2007). Specifically organic foods include less harmful additives and nutrients (vitamin $\mathrm{C}$, drymatter, minerals) and secondary nutrients (phyto-nutrients) than traditional foods. Numerous researchers (Grankvist and Biel, 2001; Lee et al., 2013; Magnusson et al., 2001)

One of the most prominent theories explaining the buying process is the Theory of Planned Behavior. The theory posits that an individual's performance of a specific behavior is determined by his or her intention to perform the behavior (Ajzen, 1991). Wu et al., (2011) defines purchase intention as the probability of consumer's readiness to purchase a product in near future. It is generally linked with the consumer's attitude, perception and buying behavior. It is observed that purchase intention is a very important factor for consumers when they are making decisions about buying any product (Fishbein and Ajzen, 1975; Ghosh, 1990)

Liljander et al., (2009) developed a similar model to Jaafar et al., (2013) in order to investigate the consumers' buying behavior in apparel category; the model took into account perceived value, perceived quality, perceived risk and store image and studied their effects on purchase intention. The study concluded that perceived quality and perceived value have direct impact on purchase intention and perceived risk negatively affects the purchase intention. Whereas store image has indirect impact on purchase intention through perceived risk and perceived quality

Study of consumers' purchase intention towards different food products does not limit to a few intrinsic and extrinsic factors; however, all the factors cannot be covered in one study, Therefore, this study attempts to build a conceptual framework which uses a combination of some important factors to explain the variation in consumers' purchase intentions towards private brands. With the 
help of the literature review a simple yet effective conceptual framework has been developed to investigate the factors affecting consumers' purchase intentions towards private brands. In this model two intrinsic factors (perceived price and perceived quality) and two extrinsic factors (packaging and perceived risk) are linked with purchase intention for food products.

\section{Variables}

Independent variables of the study are stated below:

Perceived Price.

Perceived packaging.

Perceived quality.

Perceived risk.

Whereas dependent variable is:

Purchase Intention

\section{Materials and Methods}

The ex-ante research design was used in conducting the present investigation since these products are not yet available in the market. The present study was carried out in ICAR-NDRI, Karnal and GADVASU, Ludhiana milk parlor of Northern India as the people visiting these institutes were regular consumers of dairy products. The study population comprised 100 consumers from each milk parlor of the institute who have visited regularly for purchase of milk and milk products. Thus a total of 200 respondents were selected for the investigation. A structured and pre-tested interview schedule was used to collect the information from respondents on frequency and utilization of food labels. A face-to-face self-administered questionnaire was developed as the research instrument for the present study. The questionnaire consists of five sections, using a 5-point Likert rating scale for most questions. Questions regarding perception of extrinsic factors of food products i.e. perceived price, advertisement, packaging, and store image are included in first two parts. Second part requires respondents to rate their perception towards intrinsic factors of the food product including perceived quality, risk and value. In last section, respondents rated their purchase intention towards organic and cloned animal food products.

All statistical procedures were conducted using Statistical Package for Social Science (SPSS) version 16.0. Pilot test was conducted prior to main data collection.

Based on the outcome of test to examine reliability (by scrutinizing Cronbach's alpha value) and validity of the measurement items (by using correlation analysis) and the respondents' feedback, some modifications were made to the questionnaire.

Correlation is used to look at the 'net strength' relationship between two continuous variables (Sweet and Martin, 2008). In this study, correlation is used as the predicted change in the value of the dependent variable (i.e. purchase intention) for one-unit change in the independent variable (i.e. all extrinsic and intrinsic factors of products and consumers' attitude). Guilford's (1973) rule was used to determine the correlation strength, which is depicted as in Table 1.

\section{Results and Discussion}

Data presented in the Table 2 indicated that majority of the respondents have agreed that the Price $(67.10 \%)$ is an important factor for buying power of the cloned and organic animal food products. About 64.40 percent of the respondents were perceived that the price of the cloned and organic animal food products will be compared with the traditional 
animal food products when their intention to purchase these products. On an average 60.42 percent purchase intentions depend on perceived prices of products. Similar findings are also reported from the research of Mohamed et al., (2012) who indicated that price has a great influence in determining the respondents purchase behavior.

From the Table 3 it is clearly indicated that in pooled that majority of the respondents $(68.60 \%)$ were perceived that packaging of the food items are very essential to ensure food safety followed $(66.60 \%)$ by effective packaging requirements. This was followed by similarity of packaging requirements $(64.80 \%)$ as the traditional products and good packaging (63.90\%) These findings were in line with the research of Nonis, Hudson and Hunt (2010) who reported that packaging materials have a significant impact to determine the buying behavior of the respondents.

Table 4 clearly indicated that majority (66.90\%) of the respondents were perceived that quality is an important criterion for buying the cloned and organic food products.
The same table also indicated that 65.10 percent of the respondents were also be perceived that cloned and organic animal food products will be highly nutritious.

More than half of the respondents were concerned about high quality food products and they are predicting that the cloned and organic animal food products will taste good.

Similar findings were also reported by Shepherd, Magnusson and Per-Olow (2005) who indicated that health benefits will play an important role in predicting the purchase behavior.

The data presented as in the Table 5 showed that majority of the respondents $(54.00 \%)$ were concerned about the environmental risk of the cloned and organic animal food products. Respondents are also worried about the animal welfare $(47.80 \%)$ and reduction of importance of the traditional food products (46.90\%).Similar findings were also reported from the research of Banati (2011) which indicated that people will prefer better quality products if their price is more.

Table.1 Correlation strength based on Guilford's law

\begin{tabular}{|c|l|}
\hline $\mathbf{R}$ & Strength of relationship \\
\hline $\mathbf{2 0 . 2 0}$ & Almost negligible relationship \\
\hline $\mathbf{0 . 2 0 - 0 . 4 0}$ & Low correlation; definite but small relationship \\
\hline $\mathbf{0 . 4 0 - 0 . 7 0}$ & Moderate correlation; substantial relationship \\
\hline $\mathbf{0 . 7 0 - 0 . 9 0}$ & High correlation; marked relationship \\
\hline $\mathbf{> 0 . 9 0}$ & Very high correlation; very dependable relationship \\
\hline
\end{tabular}


Table.2 Distribution of respondents according to perceived price category

\begin{tabular}{|l|l|c|c|c|c|}
\hline Sl. No & Perceived Price & \multicolumn{3}{|c|}{ Respondent categories } \\
\hline 1 & $\begin{array}{l}\text { Young } \\
\text { (n=156) }\end{array}$ & $\begin{array}{c}\text { Adult } \\
(\mathbf{n = 3 6})\end{array}$ & $\begin{array}{c}\text { Old } \\
(\mathbf{n = 8})\end{array}$ & $\begin{array}{l}\text { Pooled } \\
(\mathbf{n = 2 0 0})\end{array}$ \\
\hline 2 & $\begin{array}{l}\text { Price is important factor while buying the } \\
\text { cloned and organic animal food products. }\end{array}$ & 67.02 & 57.73 & 67.50 & 67.10 \\
\hline $\begin{array}{l}\text { Prices of cloned and organic animal food } \\
\text { products will be compared with the } \\
\text { traditional animal food products. }\end{array}$ & 64.24 & 54.09 & 80.00 & 64.40 \\
\hline 3 & $\begin{array}{l}\text { Price of the cloned and organic animal } \\
\text { food products will be reasonable for } \\
\text { shoppers. }\end{array}$ & 58.94 & 45.00 & 60.00 & 57.50 \\
\hline 4 & $\begin{array}{l}\text { Price is the important factor in buying the } \\
\text { new food products. }\end{array}$ & 64.90 & 47.27 & 65.00 & 63.40 \\
\hline 5 & $\begin{array}{l}\text { The price of the cloned and organic animal } \\
\text { food products will be lower than the } \\
\text { average market price for similar products. }\end{array}$ & 50.86 & 37.73 & 55.00 & 49.70 \\
\hline Average & 61.19 & 48.36 & 65.50 & 60.42 \\
\hline
\end{tabular}

Table.3 Distribution of respondents according to perceived packaging category

\begin{tabular}{|l|l|c|c|c|c|}
\hline S1. & Perceived packaging & \multicolumn{3}{|c|}{ Respondents categories } \\
\hline No & $\begin{array}{l}\text { Young } \\
\text { (n=156) }\end{array}$ & $\begin{array}{c}\text { Adult } \\
(\mathbf{n = 3 6})\end{array}$ & $\begin{array}{c}\text { Old } \\
(\mathbf{n = 8})\end{array}$ & $\begin{array}{c}\text { Pooled } \\
\text { (n=200) }\end{array}$ \\
\hline $\mathbf{1}$ & $\begin{array}{l}\text { Customers tend to buy the products which } \\
\text { have effective packaging. }\end{array}$ & 68.34 & 49.09 & 77.50 & 66.60 \\
\hline $\mathbf{2}$ & $\begin{array}{l}\text { Packaging of the cloned and organic animal } \\
\text { food products will look similar to the } \\
\text { traditional food products. }\end{array}$ & 65.96 & 50.45 & 70.00 & 64.80 \\
\hline $\mathbf{3}$ & $\begin{array}{l}\text { Cloned and organic animal food products will } \\
\text { have equally good packaging like traditional } \\
\text { food products. }\end{array}$ & 63.84 & 53.18 & 72.50 & 63.90 \\
\hline $\mathbf{4}$ & $\begin{array}{l}\text { Appropriate packaging on the food products } \\
\text { should display the ingredients used in the } \\
\text { food products. }\end{array}$ & 67.81 & 48.18 & 80.00 & 66.00 \\
\hline $\mathbf{5}$ & $\begin{array}{l}\text { Packaging of the cloned and organic animal } \\
\text { food products will be somehow difficult from } \\
\text { the traditional animal food products. }\end{array}$ & 53.91 & 40.00 & 60.00 & 52.80 \\
\hline $\mathbf{6}$ & $\begin{array}{l}\text { Packaging of the food products is very much } \\
\text { essential to ensure food safety. }\end{array}$ & 70.86 & 49.55 & 77.50 & 68.60 \\
\hline $\mathbf{7}$ & $\begin{array}{l}\text { Proper packaging helps to reduce the } \\
\text { different microbial contamination }\end{array}$ & 46.62 & 34.55 & 47.50 & 45.30 \\
\hline & $\quad$ Average & 62.48 & 46.43 & 69.28 & 61.14 \\
\hline
\end{tabular}

Table.4 Distribution of respondents according to perceived quality category 


\begin{tabular}{|c|c|c|c|c|c|}
\hline \multirow{2}{*}{$\begin{array}{l}\text { Sl. } \\
\text { No }\end{array}$} & \multirow[t]{2}{*}{ Perceived quality } & \multicolumn{4}{|c|}{ Respondent categories } \\
\hline & & $\begin{array}{c}\text { Young } \\
(\mathrm{n}=156)\end{array}$ & $\begin{array}{c}\text { Adult } \\
(\mathbf{n}=36)\end{array}$ & $\begin{array}{c}\text { Old } \\
(\mathrm{n}=8)\end{array}$ & $\begin{array}{l}\text { Pooled } \\
(\mathrm{n}=200)\end{array}$ \\
\hline 1 & $\begin{array}{l}\text { It is important for me to buy high quality food } \\
\text { products. }\end{array}$ & 68.08 & 48.64 & 85.00 & 65.50 \\
\hline 2 & $\begin{array}{l}\text { Quality will be an important criterion where I } \\
\text { will buy the cloned animal food products. }\end{array}$ & 64.77 & 49.55 & 82.50 & 66.90 \\
\hline 3 & $\begin{array}{l}\text { Cloned and organic animal food products will } \\
\text { be good in quality. }\end{array}$ & 66.23 & 49.09 & 75.00 & 64.00 \\
\hline 4 & $\begin{array}{l}\text { Cloned and organic animal food products will } \\
\text { be highly nutritious. }\end{array}$ & 64.24 & 49.55 & 82.50 & 65.10 \\
\hline 5 & $\begin{array}{l}\text { Cloned and organic animal food products will } \\
\text { taste good. }\end{array}$ & 63.97 & 50.91 & 77.50 & 63.50 \\
\hline 6 & $\begin{array}{l}\text { Cloned and organic animal food products will } \\
\text { clearly indicate the ingredients containing in } \\
\text { the food products. }\end{array}$ & 43.44 & 50.00 & 72.50 & 63.10 \\
\hline 7 & $\begin{array}{l}\text { Cloned and organic animal products will be } \\
\text { less associated with health risk. }\end{array}$ & 66.09 & 34.55 & 60.00 & 43.50 \\
\hline 8 & $\begin{array}{l}\text { Cloned and organic animal products are } \\
\text { chemical free and safer to eat }\end{array}$ & 65.43 & 47.27 & 62.50 & 63.80 \\
\hline 9 & $\begin{array}{l}\text { Cloned and organic animal products contains } \\
\text { more vitamins and minerals }\end{array}$ & 63.25 & 45.00 & 65.00 & 62.90 \\
\hline & Average & 68.08 & 47.17 & 73.61 & 62.03 \\
\hline
\end{tabular}

Table.5 Distribution of respondents according to perceived risk category

\begin{tabular}{|c|c|c|c|c|c|}
\hline \multirow[t]{2}{*}{ Sl. No } & \multirow[t]{2}{*}{ Perceived risk } & \multicolumn{4}{|c|}{ Respondent categories } \\
\hline & & $\begin{array}{l}\text { Young } \\
(n=156)\end{array}$ & $\begin{array}{l}\text { Adult } \\
(\mathrm{n}=36)\end{array}$ & $\begin{array}{l}\text { Old } \\
(\mathrm{n}=8)\end{array}$ & $\begin{array}{l}\text { Pooled } \\
(\mathrm{n}=200)\end{array}$ \\
\hline 1 & $\begin{array}{l}\text { Careful consideration of the cloned and } \\
\text { organic animal food products because it } \\
\text { contains risk. }\end{array}$ & 44.77 & 35.00 & 47.50 & 43.70 \\
\hline 2 & $\begin{array}{l}\text { Uncertainty of getting real value for money in } \\
\text { terms of product quality. }\end{array}$ & 47.42 & 35.00 & 50.00 & 46.10 \\
\hline 3 & $\begin{array}{l}\text { Release of cloned and organic animal products } \\
\text { will cause environmental risk. }\end{array}$ & 55.23 & 40.00 & 65.00 & 54.00 \\
\hline 4 & $\begin{array}{l}\text { Cloned and organic animal products will not } \\
\text { consider the animal being and animal welfare. }\end{array}$ & 46.62 & 41.82 & 62.50 & 47.80 \\
\hline 5 & $\begin{array}{l}\text { Cloned and organic animal products will } \\
\text { reduce the importance of traditional animal } \\
\text { food products. }\end{array}$ & 45.56 & 40.00 & 72.50 & 46.90 \\
\hline & Average & 47.92 & 38.36 & 59.50 & 47.70 \\
\hline
\end{tabular}


Table.6 Distribution of respondents according to Decision to purchase

\begin{tabular}{|l|l|c|c|c|c|}
\hline S1. No & Decision to Purchase & \multicolumn{3}{|c|}{ Respondent categories } \\
\hline $\mathbf{1}$ & \multicolumn{1}{|l|}{$\begin{array}{c}\text { Young } \\
(\mathbf{n = 1 5 6})\end{array}$} & $\begin{array}{c}\text { Adult } \\
(\mathbf{n = 3 6})\end{array}$ & $\begin{array}{c}\text { Old } \\
(\mathbf{n = 8})\end{array}$ & $\begin{array}{c}\text { Pooled } \\
(\mathbf{n = 2 0 0})\end{array}$ \\
\hline $\mathbf{2}$ & $\begin{array}{l}\text { I will consider purchasing the cloned and } \\
\text { organic animal food products. }\end{array}$ & 65.96 & 45.91 & 65.00 & 63.60 \\
\hline $\mathbf{3}$ & $\begin{array}{l}\text { I will definitely consider buying a cloned and } \\
\text { organic animal food product. }\end{array}$ & 65.03 & 50.91 & 67.50 & 64.00 \\
\hline $\mathbf{3}$ & $\begin{array}{l}\text { I will buy the cloned and organic animal food } \\
\text { products in order to get better nutrition. }\end{array}$ & 65.56 & 47.73 & 80.00 & 64.30 \\
\hline $\begin{array}{l}\text { I will recommend my friends and relatives to } \\
\text { buy organic and cloned animal food products. }\end{array}$ & 63.58 & 46.36 & 77.50 & 62.40 \\
\hline & Average & 65.03 & 47.73 & 72.50 & 63.58 \\
\hline
\end{tabular}

Table.7 Co-relation among different perceived factors with consumers purchase intention

\begin{tabular}{|l|c|c|c|c|} 
& $\begin{array}{l}\text { Perceived } \\
\text { Price }\end{array}$ & $\begin{array}{l}\text { Perceived } \\
\text { Packaging }\end{array}$ & $\begin{array}{c}\text { Perceived } \\
\text { Quality }\end{array}$ & $\begin{array}{c}\text { Perceived } \\
\text { Risk }\end{array}$ \\
\hline $\begin{array}{l}\text { Consumers Overall } \\
\text { Purchase Intention }\end{array}$ & .032 & -.022 & $.395^{* *}$ & $-.175^{*}$ \\
\hline
\end{tabular}

Note: ** Correlation is significant at the 0.01 level (2-tailed), *Correlation is significantat the 0.05 level (2-tailed)

Fig.1 Conceptual Model

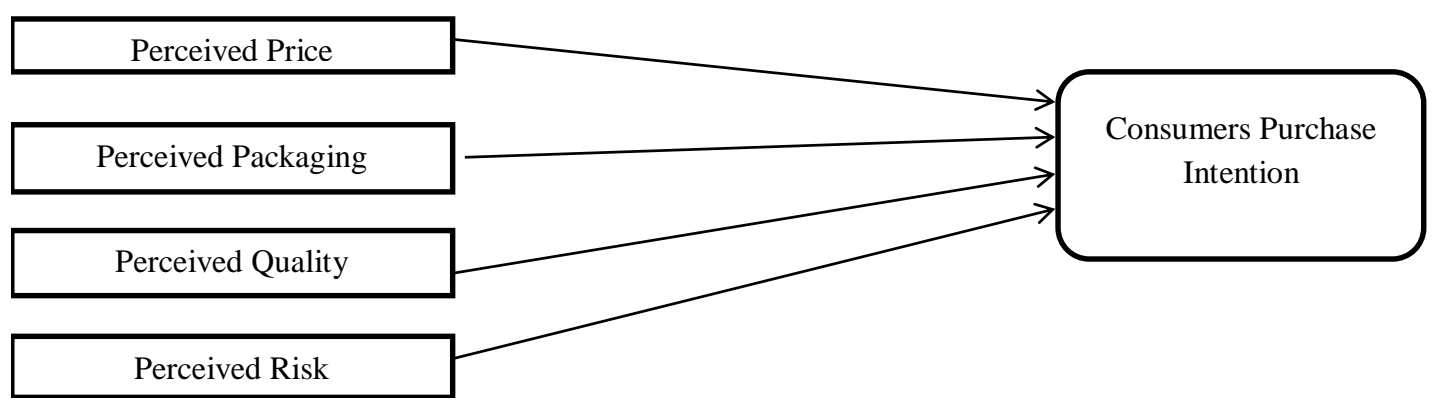

The Table 6 indicated that majority of the respondents $(64.30 \%)$ were considered better nutrition in the organic and cloned animal food products.

More than half of the respondents were considered purchasing of the organic and cloned animal food products. Similar findings were also reported by Van Loo et al., (2011) where it was indicated that better nutritious products are fetching good prices.

From the Table 7 it can be inferred that
Perceived Quality and Perceived Risk were found to have significant correlation with consumer overall purchase intention towards organic and cloned animal food products. The study of Hoch and Banegi (1993) and Sethuraman (1992) had similar findings indicating perceived risk and perceived quality affecting the purchase intention. Sudhir and Talukdar (2004) found that consumers who lacked confidence regarding the product would significantly doubt the quality of the product. As far as Perceived 
Quality is concerned a positive significant correlation was found. The higher the perceived quality of the product, the more likely consumer has intention to purchase the food product. This signifies the concerns and consciousness consumers had towards the quality to be incorporated in the organic and cloned animal food products. High quality food products would attract the consumers towards its increased purchase. Perceived risk had a significant negative correlation with purchase intention of consumer. The higher the perceived risk of the product, less likely the consumers purchase intention towards the food products (Fig. 1). The researchers during the study found that the consumers had a lot of queries and apprehensions regarding the quality of the food products to be made if available in near future. There revolves a fair share of uncertainty regarding the value of the food products. The consumers would out rightly reject the products if they are associated with risks regarding the animal welfare, environment etc. Perceived Price and Perceived Packaging were not significantly correlated to the consumer's intention toward purchase of organic and cloned animal food products.

This study concludes that perceived quality is the most important factor in predicting consumers purchase intention towards organic and cloned animal food products. Though perceived risk is negatively related with the purchase intention of the consumers, a conceptual model was developed and applied to identify the relationship between the factors and the purchase intention through corelation analysis. This products will ensure a better dairy food products market in India. Organic products will have a better sustainability and cloned animal products will contribute towards the milk and meat production. Animal cloning should be done in different animal research institutes for better quality productive animals and for the protection of the endangered species. Different livestock programmes and schemes of the Government should give importance to organic and cloned products for better production and sustainability.

\section{Acknowledgements}

The author acknowledges the ICAR-National Dairy Research Institute, Karnal for providing institute fellowship as financial support to carry out the research work.

\section{References}

Ajzen I., 1991. The theory of planned behavior. Org Behav Hum Decision Processes 50, 179-211.

Bánáti, D. 2011. Consumer response to food scandalsand scares. Trends in Food science and Technology, 22(23):560.

Chen, M. F. 2007. Consumer attitudes and purchase intentions in relation to organic foods in Taiwan: Moderating effects of food-related personality traits. Food Quality and Preference, 18: 1008-1021.

Fishbein, M., and Ajzen, I. 1975. Belief, Attitude, Intention and Behavior: An Introduction to Theory and Research. Reading, Mass: Addison-Wesley.

Ghosh, A. 1990. Retail Management. Chicago: Dryden press.

Grankvist, G., and Biel, A. 2001. The importance of beliefs and purchase criteria in the choice of eco-labelled food products. Journal of Environmental Psychology, 21: 405-410.

Guildford, J. P. 1973. Foundamental Statistics in Psychology and Education, 5th edition. New York: McGraw-Hill.

Hoch, S.J. and Banegi, S. 1993. When do private label succeed? Slogan management review. p. 57-67.

Jaafar, S. N., and Lalp, P. E. 2013. Consumers' Perceptions, Attitudes and Purchase Intention towards Private Label Food Products in Malaysia. 
Lee, W. C. J., Shimizu, M., Kniffin, K. M., and Wansink, B. 2013. You taste what you see: Do organic labels bias taste perceptions? Food Quality and Preference, 29: 33-39.

Liljander, V., Polsa, P., and Van Riel, A. 2009. Modelling consumer responses to an apparel store brand: store image as a risk reducer. Journal of Retailing and Consumer Services, 16(4): 281-290.

Liu, R., Pieniak, Z., and Verbeke, W. 2013. Consumers' attitudes and behaviour towards safe food in China: A review. Food Control, 33, 93-104.

Magnusson, M. K., Arvola, A., Koivisto Hursti, U. K., Aberg, L., and Sjoden, P. O. 2001. Attitudes towards organic foods among Swedish consumers. British Food Journal, 103: 209-226.

Miles, S., and Frewer, L. J. 2001. Investigating specific concerns about different food hazards. Food Quality and Preference, 12: 47-61.

Mohamed, M.A., Chymis, A. and Shelaby, A.A. 2012. Determinants of organic food consumption in Egypt. International Journal of Economics and Business Modeling, 3(3): 183-191.

Mondelaers, K., Aertsens, J., and Huylenbroeck, G. V. 2009a. A metaanalysis of the differences in environmental impacts between organic and conventional farming. British Food Journal, 111: 1098-1119.

Nonis A. Sarath, Hudson I. Gail, Hunt C. Shane 2010. Should WeLabel Products from Clones? An Exploratory Study of Beliefs, Attitudes and Food Safety Information on Consumer Purchase Intentions Journal of
Marketing Development and Competitiveness, 5(1): 95-96.

Schifferstein, H. N. J., and Oude Ophuis, P. A. M. 1998. Health-related determinants of organic foods consumption in the Netherlands. Food Quality and Preference, 9: 119-133.

Sethuraman, R. 1992. Understanding crosscategory differences in private label shares of grocery products. Cambridge: Marketing Science Institute. pp. 92-128.

Shepherd, R., Magnusson, M., and Per-Olow, S. 2005. Determinants consumer behaviour related to organic foods. Ambio, 34: 352359

Sudhir, K and Talukdar, D. 2004. Does store brand patronage improve store patronage? Review of Industry Organization. 24(2): 143-160.

Sweet, S.A. and Martin, K.G. 2008. Data analysis with SPSS. 3rd ed. US: America. p. 106, 123-125, 134-139,147-156

Van Loo, E.J., Caputo, V., Nayga, Jr., R.M., Meullenet, J.-F., Ricke., S.C., 2011. Consumers' willingness to pay for organic chicken breast: Evidence from choice experiment. Food Qual. Prefer. 22: 603-613

Williams, P. R. D., and Hammit, J. K. 2001. Perceived risks of conventional and organic produce: Pesticides, pathogens, and natural toxins. Risk Analysis, 21,319330.

Wu, P., Yeh, G. Y. Y., and Hsiao, C. R. 2011. The effect of store image and service quality on brand image and purchase intention for private label brands. Australasian Marketing Journal, 19(1): 30-39.

\section{How to cite this article:}

Priyajoy Kar, H.R. Meena and Neela Madhav Patnaik. 2018. Factors Influencing Consumers Purchase Intention towards Organic and Cloned Animal Food Products. Int.J.Curr.Microbiol.App.Sci. 7(01): 1-9. doi: https://doi.org/10.20546/ijcmas.2018.701.001 